Zebras surviving in the Union is unfortunately not available. The numbers appear to be as follows :-

(a) Mountain Zebra National Park (1949) .

(b) Mr. N. D. C. Michau's farm Doornhoek in the Division of Cradock (December, 1949) . ${ }^{\circ}$ 'Division of

(c) Mr. H. Lombard's farm Waterval in the Division of Cradock (December, 1949) . . . . . 11

(d) Along the northern slopes of the Outeniquas Mountains and on adjacent farms $. \quad . \quad . \quad$ (approx.) 20-25

(e) Kamanassie Area $\cdot$. $\quad \cdot \quad \cdot \quad \cdot$ (approx.) 15 ToraL . . (approx.) $\overline{69-74}$

In addition to the above, there may be a few specimens on other farms along the northern slopes of the Outeniquas Mountains."

3. Zebras for Mail Coaches.-Towards the end of the nineteenth century Mr. D. Zeederberg tried zebras in his mail coaches with the object of eliminating losses from horse sickness. He had to abandon the attempt, however, because he found the zebras (presumably E. burchellii transvaalensis from the northern Transvaal) unsuitable as draft animals.

\title{
OTHER ZEBRAS
}

\section{By T. J. STEYN}

Although scattered and greatly reduced in numbers, Hartmann's Zebras (form(s) of Mountain Zebra) still seem to occur over practically the whole mountainous coastal region of SouthWest Africa, west of the Namib, from the Orange River in the south to beyond the Cunene in the north.

Different forms of Burchell's Zebra are to be found in northern South-West Africa (Kaokoveld, Ovamboland, the Namutoni Reserve, the Kungveld, and the Caprivi Zipfel), Northern Bechuanaland, Northern and Eastern Transvaal, and in the reserves of Zululand.

No Grevy's Zebra occur within the Union, South-West Africa, or Bechuanaland. 